\title{
THE EVALUATION OF PROLONGED PAIN IN THE NEWBORN: ADAPTATION OF THE EDIN SCALE FOR THE BRAZILIAN CULTURE ${ }^{1}$
}

\author{
Flávia de Souza Barbosa Dias², Sérgio Tadeu Martins Marba ${ }^{3}$
}

\footnotetext{
${ }^{1}$ This work forms part of the dissertation - Translation, cultural adaptation and validation of the EDIN (Échelle Douleur Inconfort Nouveau-Né) scale to Brazilian Portuguese, presented to the Universidade Estadual de Campinas (UNICAMP), in 2012.

${ }^{2}$ Doctoral student, School of Nursing, UNICAMP. Campinas, São Paulo, Brazil. E-mail: flaviabdias@gmail.com

${ }^{3}$ Ph.D in Pediatrics. Professor of the Department of Pediatrics at the Faculty of Medical Sciences, UNICAMP. Campinas, São Paulo, Brazil. E-mail: sergio@caism.unicamp.br
}

\begin{abstract}
This study aims to undertake the translation and cultural adaptation of the Échelle Douleur Inconfort Nouveau-Né scale into Brazilian Portuguese, following the steps recommended internationally: a) dual translation into Brazilian Portuguese; $b$ ) a synthesis of the translations; c) back translation into the original language; d) evaluation by a panel of judges; and e) pre-testing. All internationally recommended steps were performed satisfactorily. The panel of judges made alterations in most parts of the instrument, in order to keep the semantic, idiomatic, conceptual and cultural equivalences between the original and the translated versions. Pre-testing revealed the translated version is easy to understand and to fill out, and rapid to use. The translation and cultural adaption of the EDIN into Brazilian Portuguese were successfully completed.
\end{abstract}

DESCRIPTORS: Translating. Pain. Infant, newborn. Pain measurement.

\section{AVALIAÇÃO DA DOR PROLONGADA NO RECÉM-NASCIDO: ADAPTAÇÃO DA ESCALA EDIN PARA A CULTURA BRASILEIRA}

RESUMO: Este estudo objetivou desenvolver a tradução e a adaptação cultural, da escala Échelle Douleur Inconfort Nouveau-Né para a língua portuguesa do Brasil, seguindo as seguintes etapas recomendadas internacionalmente: a) dupla tradução para a língua portuguesa do Brasil; b) síntese das traduções; c) retrotradução para a língua original; d) avaliação por comitê de juízes; e e) pré-teste. Todas as etapas recomendadas internacionalmente foram realizadas satisfatoriamente. O comitê de juízes realizou alterações, na maior parte do instrumento, com o fim de manter as equivalências semântica, idiomática, conceitual e cultural entre as versões original e traduzida. O pré-teste mostrou que a versão traduzida é de fácil compreensão e preenchimento e de rápida utilização. A tradução e adaptação cultural da EDIN para a língua portuguesa do Brasil foi realizada com sucesso.

DESCRITORES: Tradução. Dor. Recém-nascido. Medição da dor.

\section{EVALUACIÓN DEL DOLOR PROLONGADO EN EL RECIÉN NACIDO: ADAPTACIÓN DE LA ESCALA EDIN PARA LA CULTURA DE BRASIL}

RESUMEN: Este estudio tiene por objetivo desarrollar la traducción y la adaptación cultural de la escala Échelle Douleur Inconfort Nouveau-Né para la lengua portuguesa de Brasil, siguiendo los pasos recomendados a nivel internacional: a) dupla traducción para la lengua portuguesa de Brasil; b) síntesis de las traducciones; c) traducción inversa para la lengua original; d) evaluación por comités de jueces; y e) pre-prueba. Todos los pasos recomendados a nivel internacional se han realizado satisfactoriamente. El comité de jueces realizó alteraciones en la mayor parte del instrumento con el fin de mantener las equivalencias semántica, idiomática, conceptual y cultural entre las versiones original y traducida. El pre-ensayo mostró que la versión traducida es de fácil comprensión y relleno, y de rápida utilización. La traducción y adaptación cultural de EDIN para la Lengua Portuguesa de Brasil fue realizada con suceso.

DESCRIPTORES: Traducción. Dolor. Recién nacido. Dimensión del dolor. 


\section{INTRODUCTION}

The belief that the newborn (NB) was incapable of feeling pain, due to the immaturity of the central nervous system, was commonly-held among neonatology professionals for a long time. Today, it is known that the development of the pain transmission system occurs in successive stages, beginning at a very early point. The neurochemical elements necessary for the transmission of pain are evidenced from the 20th week of gestation onward, and from the 24th week one may observe the presence of sufficient nerve pathways for processing painful sensations in the brainstem. However, the ability to modulate painful stimuli, unlike the early development of the transmission mechanisms, develops only during the third trimester of the pregnancy. ${ }^{1-2}$

This being the case, newborns born prematurely or with some special need come to the Neonatal Intensive Care Unit (NICU), without their anatomy and physiology being prepared to deal with the hostility of this extra-uterine environment. To this, one can add the fact that the newborns are submitted to excessive stressful and painful stimuli which, often, are intrinsic to the undertaking of the diagnostic tests, and which are part of the clinical attendance. ${ }^{3}$

It is known that the use of pain evaluation scales can promote appropriate and efficacious treatment, reducing harm to the NB and making her inpatient treatment less painful and stressful. This not only promotes her well-being and normal development, but also complies with the health professionals' ethical and moral duty regarding the care offered to the NB receiving inpatient treatment in NICU. ${ }^{4-5}$

Among the various scales existing for evaluating pain in the newborn, ${ }^{6}$ we have focussed upon the EDIN scale (Échelle Douleur Inconfort Nouveau$\mathrm{Ne}$ ), developed in France by Debillon et al., ${ }^{7-9}$ with the aim of measuring prolonged pain in premature newborns. The authors' concern with evaluating prolonged pain instead of acute pain arose when they noted that the various pre-existing scales were not appropriate for identifying pain which lasted for hours or even days, even though it was known beyond doubt that there are various conditions which affected the NB in NICU and which can cause prolonged pain, such as abdominal distention during enteral feeding or nasal lesions during the use of non-invasive ventilation with positive pressure on the airwaves, among others.

The EDIN scale is a validated and reliable instrument. The validity of its psychometric prop- erties was ascertained following its application with 76 newborns, with gestational ages between 26 and 36 weeks, admitted to neonatal intensive and semi-intensive care units. The instrument was applied in two distinct situations: one, considered with pain, and the other without pain. The analysis of the data showed that the mean of the scores found in the situations considered painful was significantly higher $(\mathrm{p}<0.0001)$ than in the situations considered without pain, demonstrating this instrument's construct validity. ${ }^{8}$

For the verification of the EDIN's reliability, all the evaluations were undertaken simultaneously by two independent observers. The scores obtained by the two observers were compared through the calculation of the Kappa coefficient; in each one of the five indicators, the coefficient was between 0.59 and 0.74 , revealing the instrument's high reproducibility. ${ }^{8}$

The evaluation of the scale's internal consistency was verified by the Cronbach alpha test, and presented a standardized coefficient of 0.92 , proving that the five indicators have equal importance within the instrument. ${ }^{8}$

Measuring prolonged pain in newborns involves many factors which make it difficult for the professional who is providing the care to undertake a personal evaluation. The use of a specific instrument allows one to cover all the aspects of the construct which is being investigated, as well as minimizing the subjective aspects of the personal evaluation. This study proposed to undertake the translation and cultural adaptation of the EDIN scale, from its original version in French ${ }^{7}$ to Brazilian Portuguese, the aim being to provide Brazilian professionals working in neonatology with a validated and sensitive instrument for assessing prolonged pain in newborns, given that until that time, only scales for evaluating acute and postoperative pain had been adapted for the Brazilian culture. ${ }^{10-11}$

\section{METHODS}

The translation and adaptation of the EDIN scale to Brazilian Portuguese was initiated after the scale's main author authorized the undertaking of this version by email.

The internationally-recommended stages were followed throughout the process. ${ }^{12-13}$ These stages include: a) dual translation to the targetlanguage; $b$ ) the development of a synthesis version of the two translations; c) back translation of the synthesis version to the language of origin (French); d) evaluation by a panel of judges; and e) pre-testing. 
All the translations, including the back translations and the synthesis version, followed the recommendation that they should be undertaken by persons proficient in the language of origin, and whose mother tongue should be the targetlanguage. This being the case, two independent Brazilian translators, proficient in the French language, were responsible for the elaboration of the first two versions in Portuguese, a translator-reviewer, also Brazilian, and proficient in the French language, produced the synthesis-version, and two independent French translators, resident in Brazil and proficient in the Portuguese language, undertook the two back translations.

The procedures of dual translation, development of the synthesis-version and back translation were undertaken with the objective of checking the quality of the translation and ascertaining the existence of possible discrepancies between the original instrument and the translated instrument in meaning and content. ${ }^{12-13}$

The evaluation by a panel of judges aimed to evaluate whether the synthesis-version was equivalent to the original, semantically, idiomatically, culturally and conceptually, so that the necessary alterations could be made. ${ }^{12-13}$

The panel of judges was made up of seven persons: a physiotherapist with an M.Sc. in children's and adolescents' health, with experience in neonatal physiotherapy and fluency in French; a specialist neonatology nurse, fluent in French, a neonatologist, undertaking a doctorate in children's and adolescents' health, a doctor who is a full professor and a nurse Ph.D., both of whom are researchers in the issue of pain in newborns, a Brazilian certified translator, with proficiency in French, who participated in the first phase of the translation process, and a nurse with an M.Sc. in Nursing, a specialist in neonatal nursing, with experience of research in the methodology adopted in this study.

The instrument's evaluation by the panel of judges was undertaken electronically on a website developed specifically for this purpose. Each one of the members of the panel of judges was invited to participate in the study by email. Following acceptance, each one was sent a link to access the website, with their respective user name and password.

On entering the website, each one of the indicators and items of the EDIN scale was presented in its original form in French, followed by its translation into Portuguese in the synthesis-version. The evaluation consisted of choosing, for each of these indicators and items, one of the following options:
"1 - I strongly agree with the assertion"; "2 - The assertion needs minor revision to be approved"; "3 - The assertion needs major revision to be approved"; and " 4 - I do not agree with the assertion". Where options 3 or 4 were chosen, the member of the panel of judges was requested to give another suggestion for translating the assertion.

At the end of the evaluations, the Content Validity Index (CVI) was calculated for each one of the items, through the sum of the responses " 1 - I strongly agree with the assertion" and " 2 - The assertion needs minor revision to be approved", divided by the total number of responses. The value adopted as acceptable for this index was $\geq 0.70$. The translations which did not reach this level were changed and sent back for a further evaluation. ${ }^{14-15}$

Following all the evaluations, the version considered by the panel of judges was submitted to a pre-test with 30 nursing technicians who work in NICU. During the period March - April 2011, the nursing technicians used the scale for assessing the newborns who are under their care, after a minimum period of observation of three hours. They were requested to fill out a questionnaire, 'Evaluation of the Practicability of the Scale', and the opportunity was provided to criticize, and make suggestions for changes to, the items of the EDIN.

The purpose of the pre-test was to verify whether the version considered by the panel of judges was well adapted to the target-population, as well as to detect possible errors and confirm that all the items were comprehensible, assessing not only the quality of the translation, but also the practical aspects of administering it. ${ }^{12-13}$

The study did not present risk of harm to the participants' physical, mental or spiritual dimensions, respecting the content of the 1964 Helsinki Declaration and its revisions of 1975, 1983, 1989, 1996 and 2000, as well as Resolution n. 196 of 10/10/1996 of the National Health Council. All the nursing professionals who participated in the pre-test signed the terms of consent. This study's project was analyzed and approved by the Research Ethics Committee of the Faculty of Medical Sciences, Unicamp, under protocol n. 995/2010.

\section{RESULTS}

In the translation process, the differences found between the first two versions of the translation of the original in French to Portuguese were in some terms considered synonymous. These differences were resolved by the translator-reviewer. 
There were also some differences between the back translations undertaken based on the synthesis-version, in the terms translated; however, when compared individually with the original instrument, they kept the same meanings and concepts and were, therefore, considered equivalent to the original, validating the synthesis-version for the next stage of the study.

In the panel's first evaluation, the titles of the indicators translated as "Corpo", "Sono" and "Consolo" were approved without restrictions. The indicators translated as "Rosto" and "Relacionamento", in spite of also being approved, with a CVI of above 0.70 , were changed to "Face" and "Contato" respectively, due to the fact that more than $70 \%$ of the members of the panel suggested the changes.

Of the 20 proposals which describe the scale's indicators, only half were approved in the first evaluation. In the light of this, the suggestions made by the specialists were analyzed, with those that appeared repeatedly being put forward for the second evaluation.

At the end of the second evaluation, only proposal three for the indicator "Face" failed to reach the CVI adopted, it being emphasized that this was the proposal which caused the most debate, as it contains the term "Crispation" in the original in French.*

In the first two translations, this term is translated as "Espasmo", and in the synthesisversion, the translator opted for "Crispação". When examined by the panel, however, none of these translations were approved. The reason given by the panel was that "Crispação" is not a term used in our context, and that "Espasmos" does not maintain appropriate semantic equivalence. As a result, the term suggested and approved with more than $70 \%$ agreement in the third evaluation was "Contração".

The results for the CVI of evaluations undertaken by the panel are shown in figure 1 . The final version, termed EDIN - Brazilian Version, is shown in figure 2.

Figure 1 - Content validity index for each one of the items of the EDIN scale in the three evaluations undertaken

\begin{tabular}{|l|c|c|c|}
\hline \multicolumn{1}{|c|}{ Indicators - title or proposal } & $\begin{array}{c}\text { CVI } \\
\mathbf{1}^{\text {st }} \text { evaluation }\end{array}$ & $\begin{array}{c}\text { CVI } \\
2^{\text {nd }} \\
\text { evaluation }\end{array}$ & $\begin{array}{c}\text { CVI } \\
3^{\text {rd }} \\
\text { evaluation }\end{array}$ \\
\hline $1^{\text {st }}$ Title Indicator & 0.86 & - & - \\
\hline $1^{\text {st }}$ Indicator- Proposal 0 & 0.71 & - & - \\
\hline $1^{\text {st }}$ Indicator- Proposal 1 & 0.71 & 1 & - \\
\hline $1^{\text {st }}$ Indicator- Proposal 2 & 1 & - & -.71 \\
\hline $1^{\text {st }}$ Indicator- Proposal 3 & 0.14 & - & - \\
\hline $2^{\text {nd }}$ Title Indicator & 1 & - & - \\
\hline $2^{\text {nd }}$ Indicator- Proposal 0 & 1 & - & - \\
\hline $2^{\text {nd }}$ Indicator- Proposal 1 & 1 & 0.71 & - \\
\hline $2^{\text {nd }}$ Indicator- Proposal 2 & 0.71 & 1 & - \\
\hline $2^{\text {nd }}$ Indicator- Proposal 3 & 0.43 & - & - \\
\hline $3^{\text {rd }}$ Title Indicator & 1 & - & - \\
\hline $3^{\text {rd }}$ Indicator - Proposal 0 & 1 & - & - \\
\hline $3^{\text {rd }}$ Indicator - Proposal 1 & 0.86 & 0.86 & - \\
\hline $3^{\text {rd }}$ Indicator - Proposal 2 & 0.57 & 1 & - \\
\hline $3^{\text {rd }}$ Indicator - Proposal 3 & 0.57 & 0.86 & - \\
\hline $4^{\text {th }}$ Title Indicator & 0.71 & 1 & - \\
\hline $4^{\text {th }}$ Indicator- Proposal 0 & 0.14 & - & - \\
\hline $4^{\text {th }}$ Indicator- Proposal 1 & 0.86 & - & - \\
\hline $4^{\text {th }}$ Indicator- Proposal 2 & 0.86 & 0.86 & - \\
\hline $4^{\text {th }}$ Indicator- Proposal 3 & 0.57 & - & - \\
\hline $5^{\text {th }}$ Title Indicator & 1 & - & - \\
\hline $5^{\text {th }}$ Indicator- Proposal 0 & 1 & 1 & - \\
\hline $5^{\text {th }}$ Indicator- Proposal 1 & 0.71 & 1 & - \\
\hline $5^{\text {th }}$ Indicator- Proposal 2 & 0.71 & - & \\
\hline $5^{\text {th }}$ Indicator- Proposal 3 & 1 & & \\
\hline & & & \\
\hline
\end{tabular}

* The English version of the EDIN scale translates it as 'permanent grimace'. Translator's note. 
Figure 2 - EDIN - Brazilian Version

\begin{tabular}{|c|c|c|}
\hline Item & Propostas & Resultado \\
\hline Face & $\begin{array}{l}\text { 0. Face Relaxada. } \\
\text { 1. Caretas passageiras: sobrancelhas franzidas, lábios tensos, queixo } \\
\text { enrugado e tremor do queixo. } \\
\text { 2. Caretas frequentes, acentuadas ou prolongadas. } \\
\text { 3. Contração permanente, ou face prostrada, imobilizada, ou semblante } \\
\text { arroxeado. }\end{array}$ & \\
\hline Corpo & $\begin{array}{l}\text { 0. Relaxado. } \\
\text { 1. Agitação transitória, frequentemente calma. } \\
\text { 2. Agitação frequente, mas retorno para a calma possível. } \\
\text { 3. Agitação permanente, extremidades contraídas com rigidez de mem- } \\
\text { bros ou atividade motora muito pobre e limitada, com o corpo imóvel. }\end{array}$ & \\
\hline Sono & $\begin{array}{l}\text { 0. Adormece facilmente, sono prolongado, calmo. } \\
\text { 1. Dificuldade em adormecer. } \\
\text { 2. Acorda de forma espontânea e frequente mesmo sem manipulação, } \\
\text { sono agitado. } \\
\text { 3. Não dorme. }\end{array}$ & \\
\hline Contato & $\begin{array}{l}\text { 0. Sorri dormindo, sorri após estímulo, atento para ouvir. } \\
\text { 1. Apreensão passageira no momento do contato. } \\
\text { 2. Contato difícil, grita ao menor estímulo. } \\
\text { 3. Recusa o contato, nenhuma relação possível. Gritos ou gemidos sem } \\
\text { qualquer estímulo. }\end{array}$ & \\
\hline Consolo & $\begin{array}{l}\text { 0. Não necessita de consolo. } \\
\text { 1. Acalma-se rapidamente ao receber carinhos, ao som da voz ou } \\
\text { quando está sugando. } \\
\text { 2. Dificilmente se acalma. } \\
\text { 3. Inconsolável. Sucção desesperada. }\end{array}$ & \\
\hline Observações & & \\
\hline
\end{tabular}

The pre-test was undertaken in two public hospitals in the non-metropolitan region of the State of São Paulo, both linked to a States University. The nursing technicians selected to participate in this stage had more than three years' experience in NICU, and were working at the time of data collection. The newborns with whom the EDIN was used were under the care of the technicians selected to participate in the study, and were receiving inpatient treatment in the Neonatal Intensive Care Units and Neonatal Semi-Intensive Care Units. The identification data for these patients were not collected, as the objective in this phase was to evaluate the understanding of the instrument when read by the professional, and the ease with which the professional applied the instrument.

The evaluation undertaken by the nursing technicians showed that the EDIN - Brazilian Version is easy to understand and fill out. In this stage, there were no suggestions for changing any of the terms translated. The responses of the instrument for Evaluation of Practicability of the Scale are found in table 1.

Table 1 - Distribution of the responses of the nursing technicians to the questionnaire on Evaluation of Practicability of the Scale

\begin{tabular}{|c|c|c|c|c|}
\hline Variable & $\begin{array}{c}\text { Strongly } \\
\text { disagree } \\
\text { n (\%) }\end{array}$ & $\begin{array}{c}\text { Partly } \\
\text { disagree } \\
\text { n (\%) }\end{array}$ & $\begin{array}{l}\text { Partly } \\
\text { agree } \\
\text { n ( } \%)\end{array}$ & $\begin{array}{c}\text { Strongly } \\
\text { agree } \\
\text { n (\%) }\end{array}$ \\
\hline I found it easy to understand and fill out the scale & - & - & $79(23.3)$ & $23(76.7)$ \\
\hline I found it easy to understand the items for evaluation in the scale. & - & - & $7(23.3)$ & $23(76.7)$ \\
\hline The scale is fast to fill out. & - & - & $6(20.0)$ & $24(80.0)$ \\
\hline
\end{tabular}




\section{DISCUSSION}

The need to use measurement instruments in countries or languages which are different from the instrument's country or language of origin has increased significantly in recent years. This is due to the increase in the number of multicentric international research projects, as well as the need for standardized measuring of health indicators, allowing the comparison of national and international data. ${ }^{12-13}$

Although cultural adaptation requires careful attention and involves many people and a lot of time, this method is much more advantageous, when compared to developing a new instrument, given that the latter is complex and time-consuming. In addition, it requires a team which is specialized both in the phenomenon to be studied and in the process of elaborating concepts and indicators. Due to this, it is recommended that prior to initiating the development of a new measurement instrument, one should analyze the scope and limitations of all the instruments available. ${ }^{15-17}$

The EDIN scale is an instrument which is easy to use and has an exclusively behavioral approach, which allows the presentation of more consistent and specific responses regarding the concept investigated, when compared to physiological approaches. ${ }^{18}$ In addition, bearing in mind the consistency of the validation of the psychometric properties of this instrument and the applicability of the EDIN scale in other countries,, 19 we saw that this could be translated and adapted to the Brazilian culture.

The process of translation, elaboration of the synthesis-version and back translation followed the internationally-recommended steps and were concluded successfully.

The elaboration of a website for the judges' evaluation significantly contributed to the progress of the analysis, as the members did not need to meet physically. When a further evaluation was necessary, the members were contacted electronically and, using their username and password, entered the website at a time convenient to them.

In relation to the panel's evaluation, generally speaking, the translated terms were approved. When changes were necessary, the suggestions offered individually by the members were, mostly, identical or very similar.

Regarding the selection of the professionals for the pre-test, the nursing technicians were selected because the scale's authors suggest that the instrument should be applied by professionals who spend a long period of time with the patient, such that they are able to observe the indicators which are being evaluated for at least three hours. ${ }^{8}$ As a result, it is ascertained that evaluation of prolonged pain in the newborn is an issue which is totally related to the care given by the nurses, as the health professionals who work in neonatology are the only ones who spend prolonged periods of time by the bedside, allowing accurate observation regarding the indicators evaluated.

As this is a highly subjective evaluation, requiring a certain degree of knowledge of the target-population under study, nursing technicians were selected who had a minimum of three years' experience. There was concern, mainly relating to the indicators of "Contato" and "Consolo", that un-experienced professionals would have difficulty in understanding the items and choosing the appropriate proposal, as they did not have experience in the issue.

As a limitation of this study, it is emphasized that the methodological steps of translation and cultural adaptation described here ensure only the validity of the instrument's content; to ensure the construct validity, criteria validity and reliability of the version adapted to Brazilian Portuguese, further studies are necessary.

\section{CONCLUSION}

The results presented in this study demonstrate that the EDIN - Brazilian Version can be a useful instrument in the clinical practice of professionals who work in Neonatal Intensive Care Units in Brazil, promoting quality humanized care for newborns who need this type of inpatient treatment.

Further to this study, it is recommended that additional tests should be undertaken, verifying the instrument's psychometric properties, so as to ensure that the translated instrument maintains the ability to measure the concept which it is proposed to measure accurately and with an acceptable degree of reproducibility.

\section{REFERENCES}

1. Gibbins S, Stevens B. State of the art: pain assessment and management in high-risk infants. Newborn Infant Nurs Rev. 2001; 1(2):85-96.

2. Gonçalves N, Rebelo S, Tavares I. Fetal pain neurobiological causes and consequences. Acta Med Port. 2010 Mai-Jun; 23(3):419-26. 
3. Johnston CC, Fernandes AM, Campbell-Yeo M. Pain in neonates is different. Pain. 2011 Mar; 152(3 Suppl):65-73.

4. Stevens B. Acute pain management in infants in the Neonatal Intensive Care Unit. In: Finley GA, McGrath PJ, editors. Acute and procedure pain in infants and children, progress in pain research and management. Seattle (US): IASP Press; 2001. p. 101-28.

5. Bueno M, Kimura AF, Diniz CSG. Scientific evidences for managing pain in the neonatal population. Acta Paul Enferm. 2009 Nov-Dez; 22(6):828-32.

6. Silva TP, Silva LJ. Pain scales used in the newborn infant: a systematic review. Acta Med Port. 2010 Mai-Jun; 23(3):437-54.

7. Debillon T, Sgaggero B, Zupan V, Tres F, Magny JF, Bouguin MA, et al. Pain symptomatology in premature infants. Arch Pédiatr. 1994 Dec; 1(12):1085-92.

8. Debillon T, Zupan V, Ravault N, Magny JF, Dehan M. Development and initial validation of the EDIN scale, a new tool for assessing prolonged pain in preterm infants. Arch Dis Child Fetal Neo Ed. 2001 Jul; 85(1):36-41.

9. Debillon T, Guyen JMN, Ravault N. Validation statistique d'une grille d'évaluation de la douleur en néonatalogie. Arch Pédiatr. 1996 Jun; 3(6):620.

10. Bueno M, Costa P, Oliveira A, Cardoso R, Kimura A. Translation and adaptation of the Premature Infant Pain Profile into Brazilian Portuguese. Texto Contexto Enferm. 2013 Mar [acesso 2014 Fev 20]; 22(1):29-35. Disponível em: http://www.scielo. br/scielo.php?script=sci_arttext\&pid=S010407072013000100004\&lng=en\&nrm=iso\&tlng=pt
11. Alves MM, Carvalho PR, Wagner MB, Castoldi A, Becker MM, Silva CC. Cross-validation of the Children's and Infants' Postoperative Pain Scale in Brazilian children. Pain Pract. 2008 Mai-Jun; 8(3):171-6.

12. Guillemin F. Cross-cultural adaptation and validation of health status measures. Scand J Rheumatol. 1995; 24(2):61-3.

13. Beaton DE, Bombardier C, Guillemin F, Ferraz MB. Guidelines for the process of cross-cultural adaptation of self-report measures. Spine. $2000 \mathrm{Dez}$; 25(24):3186-91.

14. Alexandre NMC, Coluci MZO. Content validity in the development and adaptation processes of measurement instruments. Ciênc Saúde Coletiva. 2011 Jul; 16(7):3061-8.

15. Polit DF, Beck CT, Hungler BP. Fundamentos de pesquisa em enfermagem. $5^{\text {a }}$ ed. Porto Alegre (RS): ArtMed; 2004.

16. Duhn LJ, Medves JM. A systematic integrative review of infant pain assessment tools. Adv Neonatal Care. 2004 Jun; 4(3):126-40.

17. LoBiondo-Wood G, Harber J. Pesquisa em enfermagem. $4^{\mathrm{a}}$ ed. Rio de Janeiro (RJ): Guanabara Koogan; 2001.

18. Craig KD, Whitfield MF, Grunau RV, Linton J, Hadjistavropoulos HD. Pain in the preterm neonate: behavioural and physiological indices. Pain. 1993 Mar; 52(3):287-99.

19. Batalha L, Santos LA, Guimarães H. Pain in neonatal intensive care. Acta Pediatr Port. 2007 Jul-Ago; 38(4):144-51 